\title{
La Poesía de Manuel González-Prada
}

M ANUEL González-Prada (1848-1918) fué un hombre espiritualmente multivalente. De un lado, vibra en su ánimo la emoción del político y del ideólogo de combate; de otro, vibra en él la remansada inquietud del esteta y del versificador. Su agitada actividad de polemista, la alta sonoridad de su palabra acusadora, han opacado un tanto la fina y sugerente obra poética brotada de un espíritu culto y refinado.

A la devoción filial de Alfredo González-Prada debemos la edición reciente de muchas obras inéditas de su padre. La opera omnia no ha de venir lógicamente sino cuando Prada haya dejado de ser inédito, aunque sea en parte no esencial. La figura de este autor ha merecido en Don Manuel, de Luis Alberto Sánchez, la biografía más, animada y devota que se haya escrito hasta ahora en la literatura peruana.

En Páginas libres (París, 1894), en Horas de lucha (Lima, 1908), en innumerables panfletos y artículos periodísticos parcialmente recogidos en Nuevas páginas libres (Santiago, 1937), Bajo el oprobio (París, 1933), Anarquía (Santiago, 1936) y Prosa menuda (Buenos Aires, 1941), Prada ha escrito perdurables acápites de acusación social $\mathrm{y}$, al lado, fervorosas páginas de afirmación nacionalista. Ni en los momentos más críticos del combate deja de ser un prosador cuidadoso de la forma y pulimentador exquisito de la frase. Desdeñando a las academias y a los retóricos adocenados, era no obstante el cultor de un academismo y de una retórica a su manera. Rebelándose contra muchos dogmas, trataba de imponer, sin embargo, con su autoridad de gran escritor, un nuevo sistema ortográfico. 
Prada criticó certera y oportunamente, en medulares escritos, los vicios literarios en su época tan frecuentes y notorios; pero no puede afirmarse rotundamente que fuera un crítico literario. Pese a su alta calidad de prosador, su labor como tal corresponde ponerla con mayor justicia dentro de la historia ideológica del país.

Su talento literario creador se vuelca perdurablemente en poesía. Nacido en una época de fervor romántico, su poesía, sin él desearlo, estuvo teñida de ese romanticismo que no es escuela ni bandería sino sentimiento sincero.

¿Cuándo empezó a escribir Prada? Acaso la respuesta es mūy difícil porque el gran liberal tuvo el obstinado capricho de quemar o romper todos sus primeros originales. Se sabe que componía poesías al mismo tiempo que ensayos dramáticos fallidos. Integérrimo cultor de la forma, tuvo seguramente muy serios reparos para esta actividad de su adolescencia. Ya a los veintiún años, se pueden precisar los primeros poemas recogidos después en Minusculas ( $\mathrm{Li}$ ma, 1901). El tema preferido en toda la poesía de Prada es el amor, en contraste con lo que Enrique A. Carrillo -innegable talento crítico que quedó en potencia - anotaba en las poesías de Eguren y otros contemporáneos: ausencia del motivo amoroso. Coincidia eso con la inspiración profunda, aunque severamente romántica, que preside toda su obra poética. Su poesía iba a ser siempre el producto de sus horas de angustia, de tristeza honda, de congoja intensa. Llenan su vida años muy desolados en la primera etapa, y luego la época optimista de la edificación de su credo social. Cuando cree naber coronado la obra, el triunfo no parece fácil, los obstáculos son invencibles. La poesía es el refugio de los íntimos sufrimientos de Prada. Primero es el sufrimiento moral, más tarde aunará a él el sufrimiento físico del enfermo, con la muerte que ya lo ronda. También en esos momentos últimos la poesía es su compañera inseparable; hasta pocas horas antes de morir, pulia las estrofas de Trozos de vida (París, 1933).

Poesía la suya de firme color vital; verdad expresada por un hombre de intensa vida interior. Poesía.y verdad, sí, ambas categorías se conjugan en esta poesía auténtica.

Cierto exceso romántico en los primeros poemas se atemperó pronto. Le toca vivir durante ocho años consecutivos en el retiro de las labores campesinas, en Mala. Alternaba entonces la faena rural con la lectura y la creación literaria durante las horas del descanso 
físico. El campo tuvo la virtud de convertir una poesía vaporosa $y$ metafísica en poemas de gran fuerza expresiva por los objetivos, por lo intensamenté peruanos que resultan. Sus lecturas europeas, en vez de hacerlo imitador de los autores extranjeros como había sucedido con casi todos los poetas peruanos anteriores, le hacían volver los ojos a la realidad del paisaje, del campesino y del indio peruanos. Prada leía entonces y traducía con fervor a los poetas alemanes y lo seducían Goethe, Schiller, Ühland, Körner, Rückert y Heine. Lo que más admiraba en ellos y en su obra era el firme sentido terrígena, nacional, sobre todo en sus baladas. Sus versiones magníficas se han recogido en el volumen Baladas (París, 1939). Luego se consagra a la tarea de crear la balada peruana. Quiso encontrar la más viva entraña de la peruanidad en la historia incaica $\mathrm{y}$ en la presente virtualidad de la raza indígena, recogiendo así la voz popular, la leyenda, la conseja para sus Baladas peruanas (Santiago, 1935). Algún eco de la obra de Bécquer se ha querido hallar en la severidad y en la asonancia de algunos versos de esta etapa; simple coincidencia, porque ambos estaban àl mismo tronco germánico vinculados: el uno por la sangre, el otro por la inquietud.

Luego, con la Guerra del Pacífico, se abre un paréntesis para la producción poética de Prada. Surge entonces el animador literario que ha de transformarse luego en el caudillo político. El "Círculo Literario" que le toca presidir en 1887, se ha de convertir cuatro años después en el partido político "Unión Nacional". Una nueva generación se agrupa en su torno; en ella figuran novelistas que reflejan el ambiente del país como Mercedes Cabello de Carbonera y Clorinda Matto de Turner, autora de la primera novela de ambiente indígena, Aves sin nido. Destácanse igualmente poetas descriptivos como Germán Leguia y Martínez, Carlos Germán Amézaga y Víctor G. Mantilla. Surgen también los evocadores de costumbres como Alberto Gamarra ("El Tunante") o los animadores de leyendas populares como Ricardo Rossel. Todos son firmes en su papel de creadores del realismo y de gonfaloneros de una acción que se plasma definitivamente en nuestros días.

Se suceden los años duros de su acción política, de Propaganda $y$ ataque (título de uno de sus libros de ensayos y artículos, editado en Buenos Aires, 1939). Un viaje a Europa decide su renovación literaria por su contacto con simbolistas franceses y nuevos españoles. De regreso en 1898, ensaya Prada en sus poemas nuevas for- 
mas y nuevos metros; preocupación ésta de novedad en la estrofa y en el ritmo que fué común a casi todos los poetas de su tiempo, sobre todo a los modernistas. Vendrá, después de nuevos desencantos en la vida, un libro de poesía mejor estructurado que los anteriores, portador de una inquietud juvenil: Exóticas (Lima, 1911). Se ha dicho que este libro es el más próximo que existe a la singular poesía de José María Eguren. Prada era entonces el guía y el maestro de los jóvenes de Contemporáneos, el consejero de dudas estéticas, el animador de muchas vocaciones literarias felices. Atemperada su prédica, volvía el maestro a la creación literaria. Exóticas aporta ensayos rítmicos y combinaciones originales de silabas en el verso. $E 1$ contenido es múltiple porque tales poemas corresponden a épocas muy diversas. Es poesía interior, sin vínculo visible con la realidad que rodea al poeta transformado en intenso subjetivista. Se encuentra en este volumen desde el romántico latido hasta el logro simbolista. Preside siempre el más severo gusto artístico; la más sabia selección en el asunto y en la forma. Se afana en ser optimista, en alejar el espectro del desaliento, en dictar siempre una bella lección de vigor y de hombría. Pero, en el fondo, quien las crea siente muchísimas veces que fuerzas invencibles se oponen en su camino. Muchos hubieran tenido ya el motivo para desmayar, para abandonarse a la pesadumbre.

Nuevas horas de combate lo esperan todavía, pero muy pronto ya el límite definitivo cerrará su vida de apostolado. Prada lo siente, lo percibe con tanta claridad que, como en los momentos más críticos de su vida de luchas y de congojas, se refugia de nuevo en la poesía para hacer el recuento tácito de su vida y entonar el canto resignado a la muerte cercana. Así surgen las estrofas angustiadas de Trozos de vida. Si el adolescente se había iniciado con unos versos de corte romántico, el artista ha de despedirse de la vida también con intensas notas líricas. Entre esas dos estaciones decisivas - la aurora y el ocaso- su canción se nutre de fuertes y sinceros procesos vitales, y emerge dentro de todas las formas poéticas, sin excluir la incisiva sátira contenida en las estrofas de Grafitos (Paris, 1937).

Esta poesía ha dejado profunda huella en la literatura peruana y aun en la del Continente. Con el nombre de Prada abre Federico de Onís su ya célebre Antología de la poesía española e hispanoame- 
ricana, considerándolo como uno de los más calificados precursores del "modernismo", y con una Antología poética suya (México, 1940) inicia el Instituto Internacional de Literatura Iberoamericana su biblioteca de "Clásicos de América".

EstUaRdo NúÑEz, Lima, Perí. 
